\title{
ANÁLISIS PEDAGÓGICO DEL AULA INVERTIDA PARA EL DESARROLLO DE LA COMPRENSIÓN LECTORA Y LA PRODUCCIÓN ORAL EN EL IDIOMA INGLÉS
}

\author{
PEDAGOGICAL ANALYSIS OF THE FLIPPED CLASSROOM METHOD IN THE \\ DEVELOPMENT OF READING COMPREHENSION AND ORAL PRODUCTION IN \\ THE ENGLISH LANGUAGE
}

\author{
MSc. Luis Eduardo Prado-Yépez ${ }^{1}$, MSc. Walter Santiago Mayorga-Benavides², Lcdo. Miguel \\ Angel Román-Jaramillo ${ }^{3}$, Lcda. Magali Janeth Arevalo-Arteta ${ }^{4}$ \\ 1,2,3,4 - Universidad Central del Ecuador \\ 1. Email: leprado@uce.edu.ec ORCID: $\underline{\text { https://orcid.org/0000-0003-2374-2798 }}$
}

2. Email: wsmayorga@uce.edu.ec ORCID: https://orcid.org/0000-0001-6662-8210

3. Email: maromanj@uce.edu.ec ORCID: https://orcid.org/0000-0002-9789-9753

4. Email: mjarevalo@uce.edu.ec ORCID: https://orcid.org/0000-0002-1314-8413

Recibido: 03/05/2021 Aceptado: 29/06/2021

\begin{abstract}
Para Citar: Prado-Yépez, L. E., Mayorga-Benavides, W. S., Román-Jaramillo, M. A., \& Arévalo-Arteta, M. J. (2021). Análisis Pedagógico del Aula Invertida para el Desarrollo de la Comprensión Lectora y la Producción Oral en el Idioma Inglés. Revista Publicando, 8(30), 67-86. https://doi.org/10.51528/rp.vol8.id2201
\end{abstract}

\begin{abstract}
Resumen:
El siguiente estudio de investigación bibliográfica está orientado a presentar una revisión de la influencia del método de aula invertida en la comprensión lectora y producción oral en el idioma inglés. Este método demuestra brindar mejores oportunidades para que los estudiantes maximicen su aprendizaje en el aula de English as a Foreign Language / English as a Second Language, especialmente en lo que respecta al desarrollo de su pensamiento crítico, niveles de comprensión lectora, desarrollo de la fluidez lectora y motivación, también les brinda a los estudiantes más oportunidades para participar en clase, les ayuda a aumentar su confianza en sí mismos y un efecto positivo en la capacidad de comunicación oral en inglés de los participantes. Además, el desarrollo de la fluidez lectora es fundamental para que los estudiantes obtengan información para mejorar su comprensión lectora y su rendimiento oral. Finalmente, los hallazgos de los artículos revisados indican una influencia positiva de la implementación del método de aula invertida en estudiantes de English as a Foreign Language / English as a Second Language.
\end{abstract}

Palabras clave: Aprendizaje combinado, aprendizaje cooperativo, aula invertida, lectura comprensiva, producción oral.

\begin{abstract}
:
The following bibliographic research aimed at presenting a review about the influence of the Flipped Classroom Method on reading comprehension and oral production in the English language. This method demonstrates to provide better opportunities for students to maximize their learning in the English as a Foreign Language/English as a Second Language classroom especially regarding the development of their critical thinking, reading comprehension levels, reading fluency development and motivation, it also provides students more opportunities to participate in class, it helps them to increase their self-confidence and a positive effect on participants' English oral communication ability. Moreover, reading fluency development is essential for the students to get information and not only to improve their reading comprehension, but also their speaking achievement. Finally, the findings from the reviewed papers indicate a positive influence of the implementation of the Flipped Classroom Method on English as a Foreign Language/English as a Second Language students.
\end{abstract}

Keywords: Blended learning, flipped classroom, flipped instruction, oral production, reading comprehension. 


\section{INTRODUCTION}

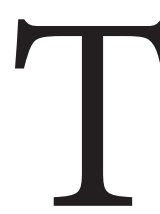

he Flipped Classroom Method is recognized among many educators and learners leads researchers to devote more time and energy to test this pedagogical strategy. The paucity of research on foreign language teaching through the Flipped Classroom Method prevents teachers from having a full understanding of its potential benefits and difficulties in foreign language classes. Inferences, deductions from the international, local scientific literature is very limited. For this reason, this research is conceived to constitute a contribution to the existing knowledge of the Flipped Classroom Method focused on the development of reading comprehension and oral production of the English language.

As explained by Bergmann and Sams (2012), flipping a classroom is about taking attention away from the teacher and focusing on the learner. Flipping seeks to eliminate a large group of direct instructions and to meet the individual needs of each student. It also offers learners the opportunity to view and read materials before class at their own pace, and if necessary, re-view and re-read the content, which are typically presented as video recordings and readings with direct questions and/or tasks. Instead of using lesson time to provide input (content), time could be spent on group discussions or tasks aimed at allowing learners to clarify, check, and consolidate their learning.

Learners are able to work within the Zone of Proximal Development (ZPD) and be prepared for problem solving under adult guidance, or in collaboration with more capable peers (Vygotsky,
1997). Activities which are commonly found in a flipped classroom such as classroom discussions, reciprocal teaching, problem-solving teaching, cooperative instead of individualistic learning or competitive learning, peer tutoring, small group learning, and questioning, are all found to have a positive impact on student learning.

\section{Inquiry Formulation}

In relation to the background of this study, the research problem was formulated in the following question:

How does the Flipped Classroom Method influence the development of reading comprehension and oral production in the English language?

\section{Research Objectives}

\section{General Objective}

To describe the influence of the Flipped Classroom Method on reading comprehension and oral production in the English language.

\section{Specific Objectives}

- To determine the efficiency of the Flipped Classroom Method on the development of reading comprehension in the English language;

- To point out the importance of the Flipped Classroom Method on the development of oral production in the English language.

\section{Pedagogical Principles of the Flipped Classroom Method}

In formal education, learners can demonstrate evidences of their own learning in qualitative 
and/or quantitative methods. Evidences could be produced when participating on learning activities such as group discussions or tests. Formal learning requires aimed, planned, and programmed educational activities. The Flipped Classroom Method binds together the learning in and out of the classroom concept, allows teachers the opportunity to rethink and reconstruct the understanding of facilitating learning. The way it perceives the time and space applied for learning enables their exploitation for more effective learning to happen. Without a time-limit class, this model offers the opportunity to focus on learners and learning through exercises and activities (Suludere, 2017). Therefore, the grounds for justifying the Flipped Classroom Method can be related to one of the most influential learnercentered approach, such as the constructivist learning theory, which in its modern sense can be attributed to Piaget, Vygotsky, and Bruner (Suludere, 2017). Basically, constructivist learning theory advocates that knowledge is built upon current or older knowledge.

In order to increase exposure to new information and for an individual to progress in learning, the relation with the environment seems to be crucial; although, in general, knowledge is acquired by interacting with the world, contacting others, and sharing experiences, which leads to the construction of new knowledge. In order to explore the Constructivist learning theory and its relevance to the Flipped Classroom Method, the perceptions of two important figures, such as Piaget and Vygotsky, who agreed on the basic concepts of Constructivist learning are presented. Although, each one underlined the importance of mental and social factors, respectively.

\section{Piaget's Constructivism}

Piaget's Cognitive Constructivist is renowned for his 'schemas', 'assimilation' and 'accommodation' components to explain how learning occurred. According to Piaget's, people have 'schemas', which reflect their understanding of the world. New information is assimilated to rely on existing mental schemas (Suludere, 2017). This stage is called 'accommodation', when individuals face problematic situations due to lack of prior knowledge, and establish links to learn new knowledge through these steps.

Piaget argued that cognitive development occurs in four stages in an unvarying order: sensorimotor, pre-operational, concrete operational, and formal operational. In order for learning to happen, Piaget maintained that its implementation in education requires teachers to create opportunities to engage learners with their own meaning-making systems and to challenge them to revise their schemas through rich and various contents (Suludere, 2017; Barr \& Keysar, 2006).

\section{Vygotsky's Constructivism}

Vygotsky's Sociocultural Constructivist perceives learning as a social phenomenon, where learning occurs through interactions in social and cultural contexts, which also means engaging with the culture presents in such society. Furthermore, cognitive development of individuals occurs in a collaborative way and it cannot be separated from social contexts (Suludere, 2017; Fernald \& Marchman, 2006). Vygotsky's observations about cognitive development are the basis of the twolayered explanation of learning, in which the first layer represents the social contact or "social plane" 
and the second layer refers to the individual reaction or "internal plane" about such contact (Moloney et al., 2016).

Another important aspect from Vygotsky' theory is the "Zone of Proximal Development" (ZPD), it underscores the difference between what people can learn independently and on their own, and what they can learn with the help of other more knowledgeable members of the society. This kind of progress builds upon older learning, goes on repeating the procedure in the learning process and it is generally known as 'scaffolding', and described by Gibbons (2015) it means "the assistance received to master a learning tasks to allow learners to perform beyond their current capacities" (p. 16). In the Flipped Classroom Method, the learners could achieve more than they might on their own by scaffolding their learning through the guidance and support of their teachers and more knowledgeable peers (Suludere, 2017).

Vygotsky explained the cognitive development through the 'internalization procedure', as a process of assisting learners to perform a task until they can accomplish it on their own. Roth \& Jornet (2017) argued that "the human mind was comprised of a lower-level neurobiological base"; however, "the human consciousness was its capacity for voluntary control over biology through the use of high-level cultural tools" (p. 97), pointed out that this major theme emerged in Vygotsky's theory as 'mediation'.

\section{Bruner's Learning Theory}

Bruner's approach emphasizes the importance of social and cultural mediation in the process of teaching-learning (Barth, 2015, p.174). One of Bruner's major themes is that learning is an active process in which learners construct new ideas or concepts based upon their current and preexisting knowledge. This cognitive structure is the network of schemas, which provides meaning and structure to experience and allows the individual to build on what is already known in order to go further. Although teachers should try to encourage learners to discover principles by themselves, teachers and learners should engage in active dialogues in order to meet this end. As Pritchard and Woollard (2010) mentioned, the role of teachers is to help in the process of transforming whatever information is to be learned into a format which is appropriate to learners' current state of understanding (p. 15).

\section{Ausubel's Theory}

According to Ausubel, learning is based upon the kinds of superordinate, representational, and combinatorial processes that occur during the reception of information. A primary process in learning is subsumption in which new material is related to relevant ideas in the existing cognitive structure on a substantive, non-verbatim basis. Cognitive structures represent the residue of all learning experiences. A major instructional mechanism proposed by Ausubel is the use of advance organizers in advance of learning itself, and are also presented at a higher level of abstraction, generality, and inclusiveness (1963, p. 81).

Ausubel emphasizes that advance organizers are different from overviews and summaries which simply emphasize key ideas and are presented at the same level of abstraction and generality as the rest of the material. Organizers act as a subsuming bridge between new learning material and existing 
related ideas. Ausubel's theory has commonalities with Gestalt theories and those that involve schema as a central principle. There are also similarities with Bruner's "spiral learning" model, although Ausubel emphasizes that subsumption involves reorganization of existing cognitive structures not the development of new structures as constructivist theories suggest. Ausubel was apparently influenced by the work of Piaget on cognitive development, the most general ideas of a subject should be presented first and then progressively differentiated in terms of detail and specificity (Ausubel, 1978); after that, instructional materials should attempt to integrate new material with previously presented information through comparisons and crossreferencing of new and old ideas, which is applied to the Flipped Classroom Model.

\section{Active Learning}

Active learning offers students the opportunity to think critically about knowledge with a range of activities which could include: collaborative learning, project-based learning, enquiry-based learning, problem-based learning, peer learning, and case studies (Reyna, 2016). Accordingly, learning requires learners to "explore and experiment with a task to infer rules, principles, and strategies for effective learning" (Bell \& Kozlowski, 2009, p. 266). Moreover, Bell and Kozlowski (2009) added that active learning means much more than learning by doing, because it exploits formal training elements to promote learning. Consequently, the active learning approach establishes a ground for flexible learning situations, in which learners involve themselves mentally and physically to deduce their own understandings.

\section{Mastery Learning}

Mastery learning refers to a shift in responsibilities, so that a student's success or failure is more reliant on the instruction and not necessarily a student's ability. The key issue in the Flipped Classroom Method is that learners learn at their own pace, anywhere, and anytime. This kind of learning supports a mastery-learning environment, learners can move to the next piece of information, chapter or unit in the curriculum after they achieve the objectives of the previous one (Suludere, 2017). According to Bloom (1956), the achievement gap among students was not the result of teaching, but it was the result of an amount of time given to learners in order to learn a subject, their backgrounds and learning styles (Guskey, 2007). This strategy suggests to provide various learning opportunities through differentiated instruction to allow all learners to achieve a better learning.

\section{Bloom's Taxonomy}

The study, published in 1956, generated a framework for educational objectives and it is known as "Bloom's Taxonomy", which is a collection of educational objectives, learning and thinking skills categorized hierarchically under six cognitive domains and it is referred as "the original taxonomy" (Bloom et al., 1956). In 2001, Anderson \& Krathwohl revised the original taxonomy to update it in accordance with the developments in education and psychology of learning. With the introduction of learnercentered approaches, terms like constructivist learning, active learning, motivation, autonomous learner and learning, self-regulated learning and metacognition have emerged. 
According to Bergmann \& Sams (2015), the Flipped Classroom Method enables the learners to reach higher levels in the taxonomy through video lessons. It is considered that video lessons are the best content-delivery tools to achieve the aims set in accordance with 'remembering' and 'understanding' levels of the taxonomy. Spires et al. (2012), pointed out that more time and focus should be given to promote cognitive processes such as creation, generation, and production, and less time to remembering since information is "abundant and can be accessed quickly" (p. 247). Such an interpretation of the revised taxonomy is called 'the inverted revised Bloom's taxonomy' and can be represented as in the Figure 1.

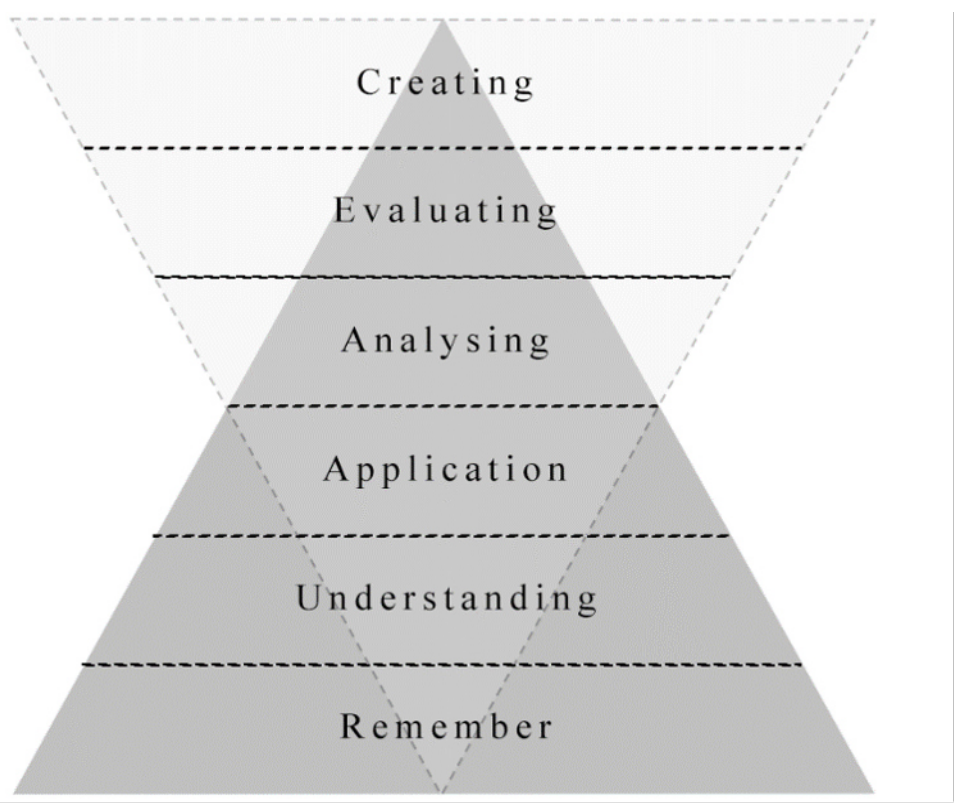

Note: From “Toward a New Learning Ecology: Professional Development for Teachers in 1:1 Learning Environments" by H. A. Spires, E. Wiebe, C. A. Young, K. Hollebrands \& J. K. Lee, 2012, Contemporary Issues in Technology and Teacher Education, 12(2), p. 248. (https://citejournal.org/volume-12/issue-2-12/currentpractice/toward-a-new-learning-ecologyprofessional-development-for-teachers-in11-learning-environments/). Copyright 2012.

The inverted version of the pyramid demands more time and effort to be spent by the learners to engage with higher tiers of the pyramid like 'creating' and 'evaluating'. When the learners are stuck due to lack of information, for example, they can always search for content without wasting much time (Bergmann \& Sams, 2015). 


\section{Collaborative Learning}

Vygotsky (1997) claimed that every individual has a ZPD, and it illustrates the importance of the social settings in constructing knowledge for individuals (Lantolf \& Thorne, 2007). In the Flipped Classroom Method, learners are to be aware of their responsibility in order to construct knowledge and the need to work collaboratively by means of previous knowledge and experience. Social technology media contribute to establish students' interaction outside the classroom and it may improve collaborative learning among students, especially when they work together virtually but at different locations.

The Flipped Classroom Method and a collaborative learning platform can support each other, and even blend together. Besides, to improve the learning process through a Flipped Classroom Method environment, it can be divided into three main collaborative stages: knowledge transmission, knowledge internalization, and capacity enhancement, where each stage corresponds to: before class, in class, and after class activities (Liu et al., 2013). In the classrooms where collaborative learning strategy is implemented, the group members work together to find a solution to a problem or accomplish a task to achieve the common aims by helping each other; abilities and contributions of the individual group members are respected and highlighted without competition or rivalry amongst the learners. Therefore, individual work gains more importance in the collaborative learning strategy in contrast to the cooperative learning strategy (Suludere, 2017).

\section{Cooperative Learning}

Collaborative learning stresses individuals, hence, the process of working together while cooperation refers to the product of such work (Suludere, 2017). Students work in small, independent groups for common educational goals, and their work is evaluated both individually and as a group. According to Johnson \& Johnson (2009), the social interdependence theory is the foundation of the cooperative learning method. The social interdependence theory suggests that individuals are affected by their own acts or those of other individuals. This theory was improved by Johnson and Johnson (2009) and designated as the cooperative learning method (Erbil, 2020).

\section{THE FLIPPED CLASSROOM METHOD}

The concept of the Flipped Classroom Method appeared in 2006 and has passed several developmental stages since then. Originally, the concept of the Flipped Classroom Method, was based on the use of videos as a medium of content transfer, while the teacher was at the center of instruction. In the next developmental stage, the concept called 'the flipped mastery model' remained focused on the teacher's transfer of knowledge, but students' learning pace was taken into account and features were added to the videos that enabled adapting to the learners' needs. The last stage of development brought about the term 'flipped learning' with the student being the center of the classroom (Koh, 2019). And, instructional strategies implemented with the aim of creating deep and lasting knowledge (Bergman \& Sams, 2014). 
The pedagogical model of the Flipped Classroom Method is the opposite of the traditional model, allowing the use of different technological tools in order to achieve a didactic and dynamic class. Students are the main protagonist of the teaching-learning process and the instructor is the person who guides and consolidates the knowledge of the learners (Sota, 2017). Platforms are used for sending instructions, materials, and information about the class to be presented on the next time. This information must be reviewed, read, and practiced by the class. Furthermore, participants can ask or clarify any doubts. This method expands learning environment beyond physical boundaries of traditional classroom with the use of technology, it consists on developing an active learning space in video before coming to classroom.

\section{THE FOUR PILLARS}

\section{Flexible environment}

Teachers create flexible environments which consist on tools and resources, whether technology-based or not, may be customized or created by others for use in the blended setting to promote language communication as the intended outcome; students choose when and where to learn, reorganizing the learning space to accommodate the lesson or unit to be taught. Besides, teachers should consider whether a virtual conference is better for students or a chaotic noise caused by them in the class hour. For Hamdan et al. (2013), this is a positive factor to help "educators build assessment systems that objectively measure understanding in a way that is meaningful to students and teachers" (p. 5).

Learning Culture
Education is actively involved in the formation of knowledge, having opportunities to participate, criticize, evaluate, and explore the topics presented at greater depth. As Bahuer-Ramazani et al. (2016) stated that "teachers need to consider the type of learners present in a classroom and their socioeconomic status, personalities, cognitive abilities, and language proficiency, as well as availability in/outside the classroom on choosing an instructional methodology" (p. 431).

\section{Intentional Content}

As Hamdan et al. mentioned that "teachers use intentional content to maximize classroom time to adopt instructional methods such as active learning strategies, instruction, problem-based learning based on grade level, and subject to be taught" (2013, p. 6). Teachers evaluate and select the content that they will need to teach directly and the appropriate content to teach by using lectures according to the complexity of the subject or diversity of students.

\section{Professional Educator}

Teachers thoroughly monitor students to determine the strategic or adaptation changes for a better understanding and comprehension. Besides, teachers during the face-to-face classes observe students' progress and provide the necessary and relevant feedback, clarifying and resolving doubts outlined by students (Hamdan et al., 2013). In this last pillar, teachers stay active, observant, and constantly moving throughout the class to provide real-time feedback, whether individual or group. 


\section{Characteristics of the Flipped Classroom}

\section{Learning pace (rhythm)}

Zapata explained that:

When we speak naturally, some words are stressed and others are not stressed. The recurrence of stressed syllables at somewhat regular and equal intervals of time determines the rhythm of speech. The interval between stresses is affected by the number of (unstressed) syllables within a single tone group and by the number and type of vowels and consonants within each syllable. (2008, p.18)

Student's learning pace, whether slow, moderate or fast, will vary according to certain factors such as age, condition and student motivation.

\section{Flexibility}

It increases the what, when, where and how people select to learn. In its broadest sense it is a continuum of approaches in terms of time, place, pace, content and model of learning applied in varying degrees. Flexibility encourages greater independence and autonomy on learners, so they can control their learning (Deakin University, 2009).

\section{Interactivity}

Learning is a pedagogical technique that engages all the students by having them actively participating with each other. Renner in her document pointed out that "interactive learning sounds like something that might require advanced technology, it's actually a pedagogical technique with a fairly simple definition. The interactive approach to any given lesson plan encourages students to interact with each other on a subject matter" (2018, paragraph 4).

\section{Critical thinking}

Critical thinking refers to reflexive activity which is used by educators to describe forms of learning, it also focuses directly on the action to solve problems by interacting with other people (Koh, 2019). Furthermore, Hitchcock in his publication about critical thinking said that "the real educational goal is recognition, adoption and implementation by students of those criteria and standards. That adoption and implementation in turn consist in acquiring knowledge, abilities and dispositions of a critical thinker" (2018, paragraph 32).

\section{Autonomous learning}

Learners have total responsibility of their learning, and besides they have the opportunity to set their own rules for the teaching-learning process. On the other hand, teachers have to develop and maintain the learning environments that support individual learning (Chicaiza, 2019).

\section{Reading Comprehension}

Pang et al. (2003) defined reading comprehension as "the process of deriving meaning from connected text. It involves word knowledge (vocabulary) as well as thinking and reasoning. Therefore, comprehension is not a passive process, but an active one" (p. 14). Reading comprehension, as stated by Barnes (2015) "is the result that operate during reading to create a mental image of the circumstances described by the text, referred to as a situation model" (p. 2). The resulting mental representation includes 
information provided by the content of the text that is integrated with the reader's knowledge to provide an evolving understanding of what is read. Klingner et al. (2007), stated that "reading comprehension is the process of constructing meaning by coordinating a number of complex processes that included word reading, word and world knowledge, and fluency" (p. 2). It includes a deep understanding in the meaning of the text rather than isolated meaning of words or phrases.

\section{Processes for Reading}

\section{Before-reading activities}

As schema theory suggests learners come to the text with a sense of what the reading will be about, it becomes an easier task because there exist more resources to draw on (Burt et al., 2003). Some of the reading activities suggested by Gibbons (2015) are: predicting from visual, predicting the main ideas, predicting from the title, first sentence or key words, sequencing illustrations or diagrams, reader questions, and storytelling in their mother language.

\section{During-reading activities}

Gibbons (2015) suggested some duringreading activities which aim to model good reading strategies and make explicit what mature readers do unconsciously, engage readers actively with the text, and help learners understand how to read more effectively by modelled reading, pause and prediction (with narrative text), shadow reading, noticing visual layout and text features, skimming and scanning the text, rereading for details, thinking tracks, making thinking explicit, sharing books, word masking, summarizing the text and jigsaw reading.

\section{After-reading activities}

As stated by Gibbons (2015) after-reading activities are based on the assumption that "learners are already familiar with the text and no longer have basic comprehension difficulties in reading it" (p. 159). They are used as a background for new learning and may fulfil any of these three major purposes: to use the now-familiar text as a basis for specific language study, to allow learners an opportunity to respond creatively to what they have read, and to focus students more deeply on the information in the text.

\section{Assessment for Reading Comprehension}

The assessment of reading comprehension involves several methods and procedures that aims to display how adequately learners are able to read, comprehend, interpret, and analyze different types of texts. Specific reading comprehension activities can be introduced in the EFL classroom in order to know how well students are able to understand a text. A reading comprehension assessment should be based on rational criteria and useful measures (Habib, 2016), who suggested the following assessment questions: Yes-No questions, TrueFalse questions, Matching, WH questions, OpenEnded questions, Multiple-Choice questions, Gapped text, and Proofreading.

\section{Oral Production}

Teachers and textbooks use direct approaches that focus on particular aspects of oral interaction, such as taking turns and managing indirect topics or approaches need communication when they want to say something and convey information. Speaking is one of the most important skills especially in learning a second language. The main 
goal of allowing educators to develop this skill is to help students to use it in a clear, effective, and professional way (Leong \& Ahmadi, 2017).

\section{Speakers' skills}

The speaker needs to be able to speak with confidence taking into account some factors like: speech production, articulation, automaticity, fluency, and also the speaker has to consider the context, the purpose of the speaking in order to give a clear message (Naveed, 2012).

\section{Types of speaking}

Rahmawati \& Hidayatullah (2014) in their paper about developing assessment for speaking stated that to develop the speaking skill is necessary to consider the following types of speaking: imitative, intensive, responsive, interactive, and extensive.

\section{Activities for speaking}

Teachers choose authentic and meaningful activities focus in real-life situations that are interesting enough to motivate students to promote communication. Some of the activities that can be used in the Flipped Classroom Method are: drilling, role play, dialogues, debates and task repetition.

\section{Assessment for speaking}

To Rahmawati \& Hidayatullah, "assessment on speaking can be a very judgmental issue, in which people tend to relate on native/nonnative speakers on the basis of pronunciation" (2014, p. 202). Some of the activities that can be use as assessment are: interviews, live monologues, recorded monologues and collaborative tasks.

\section{Data Collection Methodology}

A systematic review seeks to identify all the available evidence on a topic to reduce the effect of bias on the review findings, and it is imperative to include as many studies as possible by searching beyond academic literature alone. To identify potentially relevant studies Academia, ResearchGATE, Home / Microsoft Academic, Directory of Open Access Journals, Dialnet, RefSeek, SciELO, ERIC, Journals/ Peer Review Open Access Journals/ Hindawi, Semantic Scholar, and Wiley Online Library digital databases were initially searched. Then, Google Scholar as the source of generic literature was used in order to reach more publications which are not frequently indexed within traditional databases. The selection for this research was made according to a set of inclusion and exclusion criteria to find in publications about the Flipped Classroom Method in the field of EFL/ESL, reading comprehension and oral production.

\section{Results on the Reviewed Literature}

This literature review reveals that the implementation of the Flipped Classroom Method in the field of teaching EFL/ESL has laid great emphasis on the improvement of students' language skills. Although, it has changed the responsibility of content learning from the teacher to students in the form of active learning. In addition to this, it provides incentives for students to be active participant of their language learning, enabling students to exercise greater control of, and take greater responsibility for their own language learning. Thereby gaining confidence in language learning beyond the classroom (Alhasani 
et al., 2017).

The findings of Winda (2016), Herindayana (2017) and Chavangklan \& Suppasetseree (2018, 2019) about the impact of the Flipped Classroom Method on reading comprehension, revealed that the Flipped Classroom Method did have a significant impact on students' reading comprehension improvement compared with traditional classroom achievements on this subject, and they suggested that a longer implementation of the Flipped Classroom Method might produce better results on reading comprehension.

The Flipped Classroom Method presents a positive effect on participants' English oral communication ability and motivation, providing to students with more participation in class and helping them to increase their self-confidence, it can be implemented in speaking courses at different education levels (Sakulprasertsri \& Vibulphol, 2017). These results are compatible with the research of Yesilcinar (2019), who stated that the participants enhanced their speaking and also decreased their negative feelings towards speaking. Although, Koroglu and Cakir (2017) showed that the application of the Flipped Classroom Method helps in an effective way to develop EFL and ESL students' speaking skill proficiency. However, Li \& Suwanthep (2017) indicated that the Flipped Classroom Method combined with constructive role-plays is a more effective EFL speaking teaching method than the traditional teaching method. Learners today appreciate computers and technology.

Thus, the Flipped Classroom Method increases motivation, student-centeredness, and autonomy, allowing teachers to engage with learners in classroom activities, and for learners to watch videos or resources at home (Thanh Nguyen, 2018 \& Hamdami, 2019). Such results are aligned with the findings reported by Linh et al. (2019) and Zhang (2018) who presented remarkable achievements in pronunciation performance with the use of e-learning contents and pronunciation. Although, instructors should be provided with a professional development and technological training to help students more effectively (Ghoneim, 2017).

The Flipped Classroom Method provides students with the opportunity to learn at their own pace, allowing them to collaborate with one another, and letting them raise concerns and clarifications in a timely manner can be considered as an effective way to develop their critical thinking and reading comprehension (Fulgueras \& Bautista, 2020). Even though, findings manifest that students benefit in conventional lecturediscussion, the Flipped Classroom Method provides better opportunities for students to maximize their learning in the ESL classroom, especially with regard to the development of critical thinking and reading comprehension levels (Sin \& Siahpoosh, 2020).

Reading fluency development is essential for students, mainly at the moment when they move from learn to read to read to learn (Martins \& Capellini, 2019). All in all, the Flipped Classroom Method, a type of blended learning approach, can be an effective method in teaching and learning of EFL/ESL as it allows students to improve their language proficiency more quickly by working both in-class and out-class. The review of the literature for this research clearly shows the 
effectiveness of employing the Flipped Classroom Method in the development of reading and speaking skills in the English language. Indeed, this form of collaborative teaching and learning is expected to function as an efficient scaffolding technique in the process of learning, to increase students' participation in the actual classrooms, to bring a new trend in educational practice, and to contribute to the development of the four language skills and components among language students (Yousufi, 2019).

The implementation of the Flipped Classroom Method would enable learners to be active, motivated and engaged in English language skill tasks. It is vital for learners to perform the Flipped Classroom Method activities outside of class. Interaction-based activities and materials need to be provided to learners with the aim of helping them to produce feedback outside the classroom. Moreover, different students may find the Flipped Classroom Method more or less efficient in comparison to conventional classrooms in regards to their skills, learning styles and pre-requisite knowledge they have about the topic being taught, and some of them might have favored and others needed more guidance. There may also be an assumption that providing students with an excessive amount of time anticipates that they are pursuing the activity delightedly. Even as, the Flipped Classroom Method obliges students to study at their own pace and independently, teachers are required to instruct them and to engage students in a face-to-face discussion to provide them the possibility of asking questions, seeking clarification, and feedback.

The Flipped Classroom Method might not be proper for every individual student and subject matter. Therefore, the decision must be made by the teacher on how and when to apply the Flipped Classroom Method to assist learning. The fundamental idea is to evaluate what is needed to be taught and which online materials are proper for in-class activities. However, with a significant implementation of the Flipped Classroom Method in order to develop the reading comprehension skill among EFL/ESL students, oral production could be used as a strategy to evaluate reading comprehension.

\section{CONCLUSIONS}

In order to balance the 21st. Century students' educational demands, it is important to use innovative approaches in education. Despite the amount of research regarding the Flipped Classroom Method, little is on reading comprehension and oral production, which leads us to think that such an approach is yet to be well known. The positive development in desire, interest and motivation of educators using technological equipment will be effective in spreading this approach.

The findings from the selected papers, reveal that the Flipped Classroom Method did have a significantly impact on students' reading comprehension improvement compared with traditional classroom achievements on this subject, and a longer implementation of the Flipped Classroom Method produces better results on reading comprehension. Also, students' participation is essential, teachers must trust students to follow the instructions at home. Benefits from the Flipped Classroom Method are attributable to the executive guidance based on the knowledge schema that is established before class 
through pre-learning. Even though, the Flipped Classroom Method provides better opportunities for students to maximize their learning in the EFL/ESL classroom especially in regard to the development of their critical thinking and reading comprehension levels.

The Flipped Classroom Method presents a positive effect on learners' English oral communication ability and motivation. It provides students with more opportunities to participate in class and increases their self-confidence. Although, the Flipped Classroom Method combined with a constructive role-play is a more effective EFL/ESL speaking teaching method than the traditional teaching method. Thus, the Flipped Classroom Method increases motivation, studentcenteredness, autonomy, and allows teachers to engage with the participants in classroom activities.

The most important advantage of the Flipped Classroom Method is to increase the interaction in class. By means of lecture videos, teachers use time for team-work between the students rather than for teaching. In the Flipped Classroom Method, students can find more opportunities to discuss specific topics with their teachers, which is not a common situation in the traditional approach. Another important benefit of the Flipped Classroom Method is to motivate team-work in class. Students can access lecture videos whenever and wherever they want, and it allows students to learn at their own pace. Students who are educated with this method are encouraged to think both in and out of class. Another advantage of the Flipped Classroom Method is that parents can follow the students' courses and they can provide help to their children. In addition to all these advantages, the Flipped Classroom Method provides students time to do inventive research.

Despite all these positive facts, in literature, there are negative opinions about the Flipped Classroom Method too. Students may be stubborn at the beginning and may come to class without preparation. Also, lecture videos should be prepared carefully in a way to get students ready for the course. It is hard to prepare such good quality videos and it takes time. Additionally, obstacles preventing the use of this method may include: lack of equipment such as smart phones, tablets or computers, and internet problems. The biggest disadvantage for teachers is not preparing or broadcasting lecture videos but preparing inclass activities and integrating them into the Flipped Classroom Method. Contrary to what is known to date, this method increases teachers' work.

Finally, further studies focusing on finding solutions to reported challenges in the literature need to be carried out. Further research should be undertaken to investigate students' learning styles, cognitive, and metacognitive strategies they employ while attending a flipped language course. For an effective application and outcome of the Flipped Classroom Method by EFL/ESL learners, several factors have to be considered before its implementation. In the reviewed papers there is no evidence of initial assessment neither previous evaluation of the learners' styles nor evidence of their multiple intelligences, neither students' special needs evaluation. Moreover, all these studies were carried out on small groups of students and applied during a specific short time, thus these results would be more effective and positive if the time for the Flipped Classroom 


\section{R E V I S T A \\ Public a n d o \\ I S S N $13390-9304$}

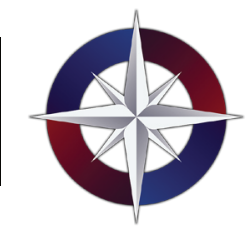

Method application would have been longer and the number of users bigger. 


\section{$\begin{array}{lllllll}\text { R } & \text { E } & \text { V } & \text { I } & S & T & A\end{array}$}

Public a n d o

I S S N $133900-9304$

\section{BIBLIOGRAPHY}

Alhasani, H., Mohd, F. W., \& Masod, M. (2017). The Effect of Flipped Classroom with Peer Instruction on ESL Students' Reading Comprehension and Engagement. International Conference ICT, Society and Human Beings, 27-34. Conference Paper. https://www.researchgate.net/ publication $/ 334786368$

Anderson, L. W., \& Krathwohl, D. R. (2001). A taxonomy for learning, teaching, and assessing. Abridged Edition. https:// executivevc.unl.edu/documents/4Revised-Blooms-Taxonomy.pdf

Ausubel, D. (1963). The Psychology of Meaningful Verbal Learning. Grune \& Stratton.

Ausubel, D. (1978). In defense of advance organizers: A reply to the critics. Review of Educational Research, 48 (2), 251-257. http://citeseerx.ist.psu.edu/viewdoc/ download?doi=10.1.1.899.3980\&rep=rep 1 \&type $=$ pdf

Bahuer-Ramazani, C., Graney, J. M., Marshall, H. W., \& Sabie, C. (2016). Flipped learning in Tesol: Definitions, approaches, and implementation. Tesol International Journal, 7.2, 429-437. https:// www.researchgate.net/publication/ 299554197

Barnes, M. A. (2015). What that models of Reading Comprehension and Its Development have to Contribute to a Science of Comprehension Instruction and Assessment for Adolescent?. In K. L. Santi \& D. K. Reed (Eds.), Improving
Reading Comprehension of Middle and High School Students (10, pp. 1-18). Springer.

Barr, D. J., \& Keysar, B. (2006). Perspective Taking and the Coordination of Meaning in Language Use. In M. J. Traxler \& M. A. Gernsbacher (Eds.), Handbook of Psycholinguistics (2nd ed., pp. 901-938). Elsevier Inc.

Barth, B-M. (2015). Bruner's Ways of Knowing. From the Cognitive Revolution to the Digital Revolution: Challenges for the Schools and Teachers of Today. In G. Marsico (Ed.), Jerome S. Bruner beyond 100 Cultivating Possibilities. Cultural Psychology of Education (Vol. 2, pp. 173184). Springer. https://doi.org/ 10.1007/978-3-319-25536-1_14

Bell, B. S., \& Kozlowski, S. W. J. (2009). Toward a Theory of Learner-Centered Training Design: An Integrative Framework of Active Learning. In S. W. L. Kozlowski \& E. Salas (Eds.), Learning, Training and Development in Organizations (pp. 263300). Routledge.

Bergmann, J., \& Sams, A. (2012). Flip your classroom: Reach every student in every class every day. Eugene, OR, USA: International Society for Technology in Education.

Bergmann, J., \& Sams, A. (2014). Flipped Learning: Gateway to Student Engagement. International Society for Technology in Education. 
Bergmann, J., \& Sams, A. (2015). Flipped Learning for Elementary Instruction. The Flipped Learning Series. International Society for Technology in Education.

Bloom, B. S., Engelhart, M. D., Furst, E. J., Hill, W. H., \& Krathwohl, D. R. (1956). Taxonomy of Educational Objectives. The Classification of Educational Goals. Handbook 1. Cognitive Domain. Longmans, Green and Co. Ltd.

Burt, M., Kreeft-Peyton, J., \& Adams, R. (2003). Reading and Adult English Language Learners, A Review of the Research. Centre for Applied Linguistics.

Chavangklan, T., \& Suppasetseree, S. (2018). Enhancing Thai EFL University Students' Reading Comprehension through a Flipped Cooperative Classroom. PEOLE: International Journal of Social Sciences, 4 (3), 238-261. https://dx.doi.org/10.20319/ pijss.2018.43.238261

Chavangklan, T., \& Suppasetseree, S. (2019). Implementing Flipped Cooperative Classroom Learning in a Reading Comprehension Course. Nakhon Ratchasima Rajabhat University Community Research Journal, 13 (1), 111-125. https://doi.org/ $10.14456 / 10.14456 /$ nrru-rdi.2019.9

Chicaiza, M. (2019). Flipped Classroom en el Desarrollo Gramatical del Idioma Inglés [Graduate's Thesis, Universidad Central del Ecuador]. Universidad Central del Ecuador Research Repository. http:// www.dspace.uce.edu.ec/handle/ 25000/19692
Deaking University. (2009). Introducing Flexible Learning. http://sitios.itesm.mx/va/ congreso_academico/documentos

Erbil, D. G. (2020). A Review of Flipped Classroom and Cooperative Learning Method within the Context of Vygotsky Theory. Frontiers in Psychology, 11 (1157), 1-9. https://doi.org/10.3389/ fpsyg.2020.01157

Fernald, A., \& Marchman, V. (2006). Language Learning in Infancy. In Traxler, M. J. \& Gernsbacher, M. A. (Eds.), Handbook of Psycholinguistics (2nd ed., pp. 10271072). Elsevier Inc.

Fulgueras, M. J., \& Bautista, J. (2020). Flipped Classroom: Its Effects on ESL Learners' Critical Thinking and Reading Comprehension Levels. International Journal of Language and Literary Studies, 2 (3), 257-270. https://doi.org/ $10.36892 / \mathrm{ijll}$ s.v2i3.228

Ghoneim, N. M. M. (2017). Using Flipperentiated Instruction to Enhance Preparatory Stage Pupils' EFL Reading Comprehension Skills. Egyptian Journals, 4, 2-28. http:// search.shamaa.org/fullrecord?ID $=124260$

Gibbons, P. (2015). Scaffolding Language Scaffolding Leaning. Teaching English Language Learners in the Mainstream Classroom (2nd ed.). Heinemann.

Guskey, T. R. (2007). Closing Achievement Gaps: Revisiting Benjamin S. Bloom's "Learning for Mastery". Journal of Advanced Academics, 19 (1), 8-31. http://doi.org/ 10.4219/jaa-2007-704 
Habib, M. (2016). Assessment of Reading Comprehension. Revista Romaneasca pentru Educatie Multidimensionala, 8(1), 125-147. http://dx.doi.org/10.18662/ rrem/2016.0801.08

Hamdan, N., McKnight, P., McKnight, K., \& Arfstrom, K. (2013). A Review of Flipped Learning. ResearchGate. https:// www.researchgate.net/publication/ 338804273

Hamdani, M. (2019). Effectiveness of Flipped Classroom (FC) Method on the Development of English Language Learning of the High School Students in Ahwaz. IJALEL: International Journal of Applied Linguistics \& English Literature, 8(2), 12-20. http://dx.doi.org/10.7575/ aiac.ijalel.v.8n.2p.12

Herdindayana, S. A. (2017). The Effect of Flipped Classroom on Students' Reading Comprehension. Journal of Language Education and Educational Technology, 2 (1).

http://dx.doi.org/10.33772/ jleet.v2i1.6699

Johnson, D. W., \& Johnson, R. T. (2009). An Educational Psychology Success Story: Social Interdependence Theory and Cooperative Learning. Educational Research. 38, 365-379. http://doi.org/ 10.3102/0013189X09339057

Klingner, J. K., Vaughn, S., \& Boardman, A. (2007). Teaching Reading Comprehension to Students with Learning Difficulties. The Guilford Press.
Koh, J. H. L. (2019). Four Pedagogical Dimensions for Understanding Flipped Classroom Practices in Higher Education: A Systematic Review. Educational Sciences: Theory \& Practice, 19 (4), 14 - 33. http:// doi.org/10.12738/estp.2019.4.002

Koroglu, Z. C. \& Cakir, A. (2017). Implementation of Flipped Instruction in Language Classroom: An Alternative way to Develop Speaking Skills of Pre-service English Language Teachers. IJEDICT: International Journal of Education and Development using Information and Communication Technology, 13(2), 42-55. https://www.researchgate.net/publication/ 321907002

Lantolf, J., \& Thorne, S. L. (2007). Sociocultural Theory and Second Language Learning. In B. van Patten \& J. Williams (Eds.), Theories in Second Language Acquisition (pp. 201 -224). https://www.researchgate.net/publication/ 237201246

Leong, L., \& Ahmadi, S. M. (2017). An Analysis of Factors Influencing Learner's Speaking Skill. International Journal of Research in English Education, 2 (1), 34-41. www.ijreeonline.com

Li, S. \& Suwanthep, J. (2017). Integration of Flipped Classroom Model for EFL Speaking. International Journal of Learning and Teaching, 3(2), 118-123. http://doi.org/10.18178/ijlt.3.2.118-123

Linh, V.T, Hoang, N., Thy, M., \& Trang, N. (2019). Flipped Classroom for Teaching Pronunciation through E-learning Materials. Semantic Scholar. https:// www.semanticscholar.org/paper/ 
$\begin{array}{lllllll}\text { R } & \text { E } & \text { V } & \text { I } & \text { S } & \text { T } & \text { A }\end{array}$

Flipped-classroom-for-teachingEnglish-through-Linh-Hoang/ 3eaf2085d1a9c1df3c239c18b59819c99f $5 \mathrm{a} 50 \mathrm{f} 8$

Liu, G., Zhang, Y., \& Fan, H. (2013). Design and Development of a collaborative Learning Platform Supporting Flipped Classroom. World Transactions on Engineering and Technology Education, 11(2), 82 - 87. http://www.wiete.com.au/journals/ WTE\&TE

Martins, M. A. \& Capellini, S. A. (2019). Relation between Oral Reading Fluency and Reading Comprehension. SCIELO: Scientific Electronic Library Online, 31(1), 1-8. https://doi.org/10.1590/2317$1782 / 20182018244$

Molony, R., Habon, L., \& Fielding, R. (2016). An Interactive, Co-constructed Approach to the Development of Intercultural Understanding in Pre-service Language Teachers. In F. Dervin \& Z. Gross (Eds.), Intercultural Competence in Education. Alternatives Approaches for Different Times (pp. 185-214). Palgrave Macmillan. http://doi.org/10.1057/978-1137-58733-6

Naveed, F. (2012). Concept of speaking and listening skills. Mass communication talk. https:// www.masscommunicationtalk.com/ concept-of-speaking-and-listeningskills.html

Pang, E. S., Muaka, A., Berhardt, E. B., \& Kamil, M. L. (2003). Teaching Reading. Educational Practices Series, 12. http:// www.ibe.unesco.org/International/

\section{Publications/pubhome.htm}

Pritchard, A. \& Woollard, J. (2010). Psychology for the Classroom: Constructivism and Social Learning. Routledge.

Rahmawati, Y., \& Hidayatullah, E. S. (2014). Developing Assessment for Speaking, Indonesian Journal of English Education, 1 (2), 199-210. http://journal.uinjkt.ac.id/ index.php/ijee/article/view/1345/1194

Renner, R. (2018). Interactive Learning Definition. The classroom. https:// www.theclassroom.com/interactivelearning-definition-5494900.html

Reyna, J. (2016). Active Learning and the Flipped Classroom. ResearchGate. Training and Development. https:// www.researchgate.net/publication/ 311681438

Roth, W-M., \& Jornet, A. (2017). Understanding Educational Psychology. A Late Vygotskian, Spinozist Approach. Cultural Psychology of Education (3). Springer. http://doi.org/10.1007/978-3-319-39868$\underline{6}$

Sakulprasertsri, K. \& Vibulphol, J. (2017). Effects of English Instruction using the Flipped Learning Approach on English Oral Communication Ability and Motivation in English Learning of Upper Secondary School Students. ResearchGate 44(3), 29$45 . \quad$ https://www.researchgate.net/ publication/328449142

Sin, S. L., \& Siahpoosh, H. (2020). Looking at the Impact of the Flipped Classroom Model on Reading Comprehension of Iranian 
EFL Learners. Arabic Language, Literature \& Culture, 5 (2), 14-22. 10.11648/j.allc.20200502.12

Sota, M. S. (2017). Variation in time, place, pace: Blended learning and flipped classroom. Center on Innovations Learning, 1-16. http://www.centeril.org/publications/ BlendedLearning.pdf

Spires, H. A., Wiebe, E., Young, C. A., Hollebrands, K., \& Lee, J. K. (2012). Toward a New Learning Ecology: Professional Development for Teachers in 1:1 Learning Environments. Contemporary Issues in Technology and Teacher Education, 12(2), 232-254.

Suludere, H. N. (2017). Learning in the 21 st. Century: The Flipped Foreign Language Classroom [Ph. D. Thesis, Universitá Ca’Foscari Venezia]. http:// hdl.handle.net/10579/10332

Thanh, Q. T. \& Nguyen, L. (2018). Flipped Model for Improving Students' English-Speaking Performance. Can Tho University Journal of Science, 54(2), 90-97. http://doi.org/ $10.22144 /$ ctu.jen.2018.012

Vygotsky, L. S. (1997). Interaction between Learning and Development. In $\mathrm{M}$. Gauvain \& M. Cole (Eds.), Readings on the Development of Children (2nd ed., pp. 34-40). W. H. Freeman and Company.

Winda, S. (2016). The Impact of Flipped Classroom on Reading Comprehension of High School Students with Different Cognitive Learning Styles. Medium for English Language Teaching Journal, 1 (1),
17-33. $\quad$ http://dx.doi.org/10.22303/ melt.1.1.2016.17-33

Yesilcinar, S. (2019). Using the Flipped Classroom to Enhance Adult EFL Learners' Speaking Skills. PASAA: A Journal of Language Teaching and Learning, 58, 206-234. https://www.researchgate.net/ publication/336287505

Yousofi, U. (2019). A Review of Flipped Classroom Model. Global Scientific Journals, 7 (12), 660-669. http:// www.globalscientificjournal.com

Zapata, A. A. (2008). Stress and Rhythm. Web del professor. http://webdelprofesor.ula.ve/ humanidades / azapata / materias / phonetics_1/stress_and_rhythm.pdf

Zhang, L. (2018). An Experimental Study on Flipped Classroom of English Pronunciation. Semantic Scholar, (223), 179-182. http://doi.org/10.2991/ICEESS18.2018 .44 